\title{
Induction Chemotherapy in Head and Neck Squamous Cell Carcinoma
}

\author{
Daris Ferrari*, Antonio Marra, Martina Violati, Teresa Beninato, Francesca Broggio and Carla Codecà \\ Medical Oncology Unit, ASST Santi Paolo e Carlo, University of Milan, Milan, Italy
}

Submission: May 21, 2018; Published: June 15, 2018

*Corresponding author: Daris Ferrari, Medical Oncology Unit, ASST Santi Paolo e Carlo, University of Milan, Via Antonio di Rudinì, 8, 20142, Milan, Italy, Email: daris.ferrari@asst.santipaolocarlo.it

\section{Abstract}

The role of induction chemotherapy added to standard local treatments for loco-regionally advanced head and neck squamous cell carcinoma has been deeply investigated in the last years. Despite the results of several clinical trials, highlighting a substantial benefit on patients' outcomes from this approach, a clear consensus on its optimal clinical application has not been defined yet. Moreover, with the exception of patients with laryngeal tumors for which induction chemotherapy is a widely accepted treatment for organ preservation, the use of this therapeutic approach in head and neck tumors of different sites is not consensually adopted by national and international guidelines. The aim of this review is to

a) Describe the current evidence about the role of induction chemotherapy in patients with locally advanced head and neck tumors.

b) Point out its use in selected patients, such as those affected by laryngeal cancer or HPV-positive tumor.

c) Highlight the unmet needs which will have to be defined in the next years and in further clinical trials.

Keywords: Head and Neck Squamous Cell Carcinoma; Induction Chemotherapy; Cetuximab; Laryngeal Preservation; Trailblazers Trials; LocalRegional Control; Cisplatin; Hematological Toxicity, Specifically Neutropenia, Febrile Neutropenia

Abbreviations: 5-FU: Fluorouracil; CR rate: Complete Response Rate; CRT: Chemo Radio Therapy; CT: Chemo Therapy; DF-FS: Distant FailureFree Survival; DFHX: Docetaxel Fluorouracil and Hydro Xyurea; DoR: Duration of Response; ICT: Induction Chemo Therapy; LASCCHN: Locally Advanced Squamous Cell Carcinoma of the Head and Neck; LPR: Larynx Preservation Rate; LRC: Locoregional control; MO: Months; NS: Not Significant; ORR: Overall Response Rate; OS; Overall Survival; PF: Cisplatin Plus 5-FU; PFS: Progression-Free Survival; RFS: Relapse Free Survival; RTX: Radiotherapy; SCCHN: Squamous Cell Carcinoma of the Head and Neck; TTF: Time to Treatment Failure; TPF: Docetaxel Cisplatin and 5-FU

\section{Introduction}

The role of induction chemotherapy (IC) in loco-regionally advanced squamous cell carcinoma of the head and neck (LASCCHN) has been extensively investigated in the last years. Although various trials have been concluded and few meta-analyses performed, the right collocation of IC is still debated. IC was developed with the aim of improving the results of chemoradiotherapy (CRT) or radiotherapy (RTX) in LASCCHN, since almost half of the patients are candidate to develop recurrent/metastatic disease. The main objective of IC has classically been tumor cell destruction at an early stage of disease and, as a consequence, the reduction of distant dissemination. A further step ahead would be the improvement of disease-free and overall survival (DFS and OS). Unfortunately, such a simplified series of events has not been uniformly demonstrated, so oncologists are still discussing whether and when to administer IC and which patients are best candidates.

Trailblazers trials suggested that IC could play a new role in patients with advanced laryngeal cancer or LASCCHN. IC demonstrated to be effective in preserving the larynx in a high percentage of patients, without compromising OS, and in improving the response rate and local-regional control [1-3]. However, conflicting data were provided by different authors who compared IC followed by surgery and postoperative RTX with surgery and postoperative RTX, finding no difference in survival [4]. The real milestone that contributed to better understand the efficacy of IC in LASCCHN is the meta-analysis published by Pignon and updated in 2009. The role of IC was evaluated in 5311 patients from 31 trials. The hazard ratio (HR) for death was $0.96(0.90-1.02 ; \mathrm{p}=0.18)$ in favor of induction chemotherapy with an absolute benefit of $2.4 \%$ at 5 years. There was no significant variation $(\mathrm{p}=0.23)$ of the effect according to the type of chemotherapy: 0.90 (0.82-0.99) for 5-FU-platin, 1.01 (0.91-1.12) for different poly-chemotherapy, and 0.99 (0.841.18) for mono-chemotherapy (not containing platin). Compared to this marginal absolute advantage, the benefit of IC in reducing distant failures was significant and more pronounced $[4.3 \%$ at 5 years, HR 0.73 [0.61-0.88], $p=0.001)[5,6]$. 
A clear lesson to be learned from this study is the importance of the quality of chemotherapy (CHT), namely the choice of a combination of cisplatin and 5-fluoruracil (5-FU) or a triplet consisting of cisplatin, 5-FU and a taxane (TPF regimen). Such a question has been indubitably solved by 3 phase III randomized controlled clinical trials on different LASCCHN populations demonstrating the superiority of the TPF regimen in terms of overall response rate (ORR), progression-free survival (PFS) and OS, together with a superior toxicity profile [7-9]. In TAX 323 trial [8] the ORR in the TPF group was significantly higher than in the PF group, and TPF also resulted in a relative reduction of $28 \%$ in the risk of disease progression or death $(\mathrm{p}=0.007)$. Median OS was 18.8 vs 14.5 months in favor of TPF arm. In the better-prognosis population of TAX 324 trial [9], treatment with TPF resulted in a significant $30 \%$ reduction in the risk of death $(p=0.006)$. Median survival was 71 months in the TPF group and 30 months in the PF group ( $\mathrm{p}=0.006)$, while estimated 3-year survival rates were $62 \%$ and $48 \%(p=0.002)$, respectively [10].

Further confirmation of these suggestions derives from a recent meta-analysis by Blanchard et al. which evaluated data from 5 phase III studies, representing a total of 1772 patients. The authors concluded that patients treated with TPF versus PF have better PFS, OS, locoregional failure rate (LFR) and distant failure rate (DFR). The HR for death was estimated to be 0.79 in favor of TPF [10]. Noteworthy is the confirmed safety of a 3-drug regimen compared to the classical cisplatin-5-FU doublet, associated with higher efficacy. TPF was burdened by fewer grade 3/4 mucositis events, and less pronounced nausea, vomiting and hearing loss. Moreover, a lower rate of toxic deaths was registered in the TPF arm that, however, increased hematological toxicity, specifically neutropenia, febrile neutropenia, and leukopenia. In order to avoid serious consequences to the patients it would be advisable to administer TPF as in TAX 323 or the GSTTC Italian Collaborative Group study trials, where a reduced dose of CHT was used $[8,11]$.

The impact of IC on quality of life (QoL) has been evaluated in the TAX 323/EORTC 24971 trial. TPF proved to be superior to PF in improving QoL measured at 6 months after treatment initiation, using the European Organization for Research and Treatment of Cancer (EORTC) QoL Questionnaire C30, mainly as far as swallowing difficulties and coughing problems are concerned [12]. It should be kept in mind that IC regimens are always challenging treatments and must be administered under the control of experienced oncologists. Both the pharmacologic toxicity and the patients' severe clinical conditions make supportive and palliative care protocols essential to take care of head and neck cancer patients in all their clinical complexity. To fulfill this hard task, all the choices should be made in the context of a multidisciplinary team, composed by the physicians directly involved in treatment decision (oncologist, surgeon, radiotherapist) and the specialists experienced in psychological, nutritional, rehabilitative and palliative care $[13,14]$.

\section{Phase III clinical trials analysis}

The answer to the question whether IC is significantly useful in LASCCHN has not come from 2 recent American trials. The PARADIGM study randomized patients to receive either IC (three cycles of TPF) followed by concurrent CRT or definitive concurrent CRT, with OS as a primary end-point. The trial closed prematurely for insufficient accrual and low power to see the predicted difference in OS because survival was better than expected in both groups [15]. Not even the DECIDE trial, enrolling patients with a confirmed diagnosis of N2 or N3 LASCCHN, was able to confirm the advantage of IC followed by CRT on CRT alone in terms of OS, distant failure-free survival and recurrence-free survival. Unfortunately, the trial was underpowered because it did not meet the planned accrual target, so not definite conclusions on the role of IC can be drawn [16-26].

The recently published phase II/III study by Ghi et al. [27] compared IC with TPF followed by CRT or cetuximab/RTX with the concomitant treatments without IC in a mixed population of patients with low surgical curability or functionally inoperable stages III-IV LA SCCHN of the oral cavity, oropharynx and hypopharynx. The CHT contemplated during CRT was a relatively low cumulative dose of cisplatin $(160 \mathrm{mg} / \mathrm{m} 2)$ in combination with infusional 5-FU. In the evaluation of IC versus no-IC, the results suggested a significant improvement in OS, PFS and locoregional control (LRC) in patients receiving TPF $[11,17]$. The differences in favor of IC were quite impressive. Median and 3-year OS were 54.7 vs 31.7 months and $57.5 \%$ vs $46.5 \%$, respectively, while median and 3-year PFS were 30.5 vs 18.5 months and $47 \%$ vs $38.5 \%$, respectively. Toxicity in the TPF arm was as expected, while compliance with concomitant treatment, independently from the type of concomitant strategy, was similar in the IC and no-IC arms. Furthermore, considering the low mortality rate in experienced hands, TPF followed by CRT or RTX and cetuximab can be considered a new standard option for LASCCHN [16]. When considering patients with operable disease, the results of adding IC to CRT are much less convincing. In fact, less recent studies, failed to demonstrate a survival benefit with induction versus locoregional treatment $[4,8,19]$ and such a discouraging result has been confirmed by the meta-analysis of Ma et al. on more than 2000 patients [20].

\section{Induction Chemotherapy and Laryngeal Cancer}

The only setting where IC has gained uniform consent as an effective treatment is resectable LA laryngeal cancer. With the aim of organ preservation, patients with laryngeal or hypopharyngeal cancer who require total laryngectomy can be managed with sequential or concurrent CRT, with surgery as a secondary salvage option. In a phase III trial, IC followed by RTX demonstrated to lead to a $31 \%$ complete response rate and $54 \%$ partial response rate, with $53 \%$ of patients still alive at 3 years $[1,21]$. In the pre-TPF era, Lefebvre et al. investigated IC with PF followed by radiotherapy, leading to survival rates of $45 \%$ with 
functional larynx and 36\% overall at 5 years [22]. Subsequently, TPF IC demonstrated even more efficacy in larynx preservation, leading to an ORR after IC of $80.0 \%$ (41.8\% CR and 38.2\% PR) in the TPF group and $59.2 \%$ (30.1\% CR and $29.1 \%$ PR) in the $\mathrm{PF}$ group (difference $=20.8 \%$; $\mathrm{p}=0.002$ ). Larynx preservation rate was $70.3 \%$ following TPF and $57.5 \%$ after the PF regimen (difference $=12.8 \% ; \mathrm{p}=0.03$ ). No significant difference was registered for OS between the 2 arms (60\% each) [23].

In the RTOG 91-11 [24] comparing sequential chemotherapy (PF) and radiation with concomitant CRT and RTX alone in patients with LA laryngeal cancer, OS did not differ significantly between induction and concomitant groups, although there was a trend toward a worse outcome with concomitant CRT (HR 1.25; $95 \%$ CI, 0.98 to $1.61 ; \mathrm{p}=0.08$ ). However, the larynx preservation rate was significantly superior with CRT over IC followed by RT (HR 0.58; 95\% CI, 0.37 to $0.89 ; \mathrm{p}=0.005$ ) and over RT alone. The 10 -year update analysis indicated a significant improvement in laryngectomy-free survival and a trend in improved OS with sequential CHT over concurrent CRT. Although no difference in late effects was detected, concomitant CRT caused more deaths not attributed to cancer or treatment (30.8\% vs $20.8 \%$ with IC). In the TREMPLIN trial [25] patients who developed a tumor response $(\geq 50 \%)$ after three cycles of TPF IC were randomized to receive conventional RTX with concurrent cisplatin or concurrent cetuximab. No significant difference in terms of larynx preservation (95\% vs 93\%), larynx function preservation ( $87 \%$ vs $82 \%$,) and 18 -months OS ( $92 \%$ vs $89 \%$ ) were observed.

\section{Induction Chemotherapy and Human Papilloma Virus}

Several retrospective and prospective trial have shown that among patients with oropharyngeal squamous-cell carcinoma, Human Papilloma Virus (HPV) positive tumors have a better prognosis than HPV-negative tumors [26-29]. Indeed, patients with HPV-associated LA SCCHN tend to respond better to therapy, leading to longer OS compared to HPV-negative patients. A retrospective analysis of the association between tumor HPV status and survival among patients with LA oropharyngeal squamous-cell carcinoma enrolled in a randomized trial comparing cisplatin and accelerated-fractionation RTX with cisplatin and standard-fractionation RTX, demonstrated that tumor HPV status is a new strong and independent prognostic factor for survival beyond the previously well-known risk factors such as pack-years of tobacco smoking, tumor stage, and nodal stage [30].

The value of IC in HPV-associated oropharyngeal cancer has been demonstrated in 2 randomized trials that evaluated either the combination paclitaxel/carboplatin or the TPF regimen in LA disease. In Fakhry's trial, patients with HPV-positive tumors had higher response rates after IC ( $82 \%$ vs $55 \%$; $\mathrm{p}=0.01)$ and at the completion of CRT ( $84 \%$ vs $57 \%$; $\mathrm{p}=0.007$ ) and improved 2 -year OS (95\% vs 62\%; p=0.005) [29]. A subset analysis of the TAX 324 trial demonstrated that HPV-positive patients can achieve superior survival with IC. After almost 7 years median follow-up, OS and PFS rates were 79\% and 73\% for HPV-positive patients, compared with 31\% OS and 29\% PFS for HPV-negative patients (both $\mathrm{p}<0.0001$ ). The median OS time for HPV-positive patients was not reached while it was 21 months in HPV-negative patients with an $80 \%$ reduction in mortality in the former group $(p<0.0001)$ [31]. In order to avoid or reduce early and late toxicities linked to RTX, IC has been selected as an ideal therapy, able to allow a reduction in radiation dose intensity [32].

A phase II de-escalation trial demonstrated that IC (cisplatin, paclitaxel, cetuximab) followed by weekly cetuximab plus reduced-dose intensity-modulated radiation therapy (IMRT), compared with standard IMRT, significantly decreased the rate of RTX-associated difficulty in swallowing solids or impaired nutrition ( $40 \%$ versus $89 \%$; $p=0.011$ and $10 \%$ versus $44 \%$; $\mathrm{p}=0.025$, respectively). Efficacy was not affected in IC responders [33]. These interesting results provide justification for further studies of RTX de-intensification and confirmation in larger prospective trials. With the aim of treating to the best any single patient, maximum attention must be given to patients' selection. Responders to IC (and possibly non-smokers) are likely to be the best candidates to de-escalating treatment.

\section{Discussion}

The treatment of head and neck cancer is a hard task, requiring a multidisciplinary approach with the intent of offering the best therapeutic option to the patients. In case of LASCCHN, CRT is currently the standard treatment for the majority of patients. Nevertheless, tentative superior strategies have been widely investigated. Among them, IC followed by RTX, CRT or bio-radiotherapy has gained popularity in the recent years but, owing to the high toxic potential, it should be reserved to selected patients. IC followed by local treatment demonstrated to be very effective in larynx preservation, and this option is highly recommended as OS is not affected by a conservative approach that foresees surgery as a salvage plan. It is difficult to say what can be considered the best local treatment following IC but, reasonably, cetuximab and RTX can be considered an effective and safe alternative to cisplatin-based concomitant CRT.

On the other hand, oncologists are faced with oropharyngeal carcinoma, a tumor characterized by increasing incidence and often linked to HPV. High-risk types of HPV, mainly HPV type 16 (HPV-16) enhance the expression of viral E6 and E7 oncoproteins that inactivate the tumor-suppressor proteins p53 and the retinoblastoma protein (pRb), respectively [26]. Although the penetration of HPV into oropharyngeal cells is necessary for malignant transformation [27], the presence of the virus improves the prognosis, opening the way to integrated toxicity-sparing treatments. High RR and long survival have been associated with IC in oropharyngeal HPV-positive cancer. In order to reduce the toxicity related to RTX, while maintaining the same efficacy, the results of forthcoming de-escalating trials are eagerly awaited. 
For oral cavity, tongue, oropharyngeal HPV-negative and hypopharyngeal cancer the role of IC is still to be confirmed. Looking at most of the trials a few suggestions can be made:

a) If IC is going to be chosen, TPF is the preferred regimen since it demonstrated to be more effective and less toxic than PF [8-9].

b) In case of oral cancer, IC followed by surgery failed to confer any advantage over surgery alone but, in not operable cases, IC followed by CRT can be a marginal option to decrease the tumor volume and the patient's symptoms [34]. c) High-risk patients (risk of distant failure for hypopharyngeal cancer, multiple nodes, large-volume nodal disease and low nodes) can take great advantage from a sequential approach [35] mainly due to a reduction in distant failures [36].

d) IC followed by either RTX, CRT or bio-radiotherapy puts an additional burden on the patients in terms of toxicity, so it is maximally important that such treatments are managed at high volume centers by skilled multidisciplinary teams $[11,14]$.

\section{Conclusion}

Table 1: Phase II-III clinical trials evaluating ICT in HNSCC.

\begin{tabular}{|c|c|c|c|c|c|c|c|c|}
\hline \multirow[b]{2}{*}{ Trial } & \multirow[b]{2}{*}{ Population } & \multirow[b]{2}{*}{ IC Regimen } & \multirow[b]{2}{*}{ Control Arm } & \multirow[b]{2}{*}{$\begin{array}{l}\text { Primary } \\
\text { Endpoint }\end{array}$} & \multirow[b]{2}{*}{$\begin{array}{c}\text { Secondary } \\
\text { Endpoint }\end{array}$} & \multirow[b]{2}{*}{ Outcome(s) } & \multicolumn{2}{|c|}{ Rate of Toxic Death } \\
\hline & & & & & & & $\begin{array}{l}\text { During } \\
\text { ICT }\end{array}$ & $\begin{array}{l}\text { During } \\
\text { whole } \\
\text { Treatment }\end{array}$ \\
\hline $\begin{array}{l}\text { Hitt R, JCO [7] } \\
\quad \text { (Spain) }\end{array}$ & $\begin{array}{l}\text { Stage III or IV } \\
\text { LASCCHN }\end{array}$ & $\begin{array}{c}\text { TPF } \rightarrow \\
\text { cisplatin- } \\
\text { RTX/surgery }\end{array}$ & $\begin{array}{c}\text { PF } \rightarrow \\
\text { cisplatin- } \\
\text { RTX/surgery }\end{array}$ & CR rate & $\begin{array}{c}\text { TTF } \\
\text { OS } \\
\text { Organ } \\
\text { preservation } \\
\text { rate } \\
\text { Toxicity }\end{array}$ & $\begin{array}{c}\text { CR rate } \rightarrow 33 \% \text { vs } \\
14 \%(p=.001) \\
\text { TTF } \rightarrow 20 \text { vs } 12 \text { mo } \\
\quad(p=0.006) \\
\text { OS } \rightarrow 43 \text { vs } 37 \text { mo } \\
\quad(p=0.06) \\
\text { Organ preservation } \\
\text { rate } \rightarrow 63 \% \text { vs } 52 \% \\
\quad(P=0.049)\end{array}$ & $\begin{array}{c}4 \% \text { vs } \\
2 \%\end{array}$ & $\begin{array}{l}2 \% \text { vs } 0.5 \% \\
\text { (during } \\
\text { CRT) }\end{array}$ \\
\hline $\begin{array}{c}\text { Vermorken J, } \\
\text { NEJM [8] } \\
\text { (TAX 323/ } \\
\text { EORTC } \\
24971 \text { ) }\end{array}$ & $\begin{array}{l}\text { Stage III or IV } \\
\text { LASCCHN }\end{array}$ & $\mathrm{TPF} \rightarrow \mathrm{RTX}$ & $\mathrm{PF} \rightarrow \mathrm{RTX}$ & PFS & $\begin{array}{c}\text { OS } \\
\text { ORR } \\
\text { DoR } \\
\text { TTF } \\
\text { Toxicity }\end{array}$ & 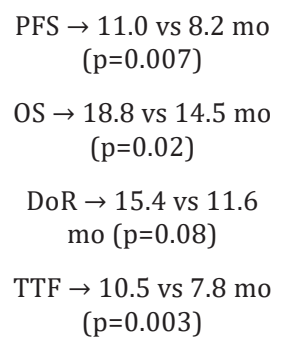 & NA & $\begin{array}{c}5.5 \% \text { vs } \\
2.3 \%\end{array}$ \\
\hline $\begin{array}{l}\text { Posner MR, } \\
\text { NEJM [9] } \\
\text { (TAX 324) }\end{array}$ & $\begin{array}{l}\text { Stage III } \\
\text { or IV non } \\
\text { metastatic, } \\
\text { unresectable } \\
\text { or of low } \\
\text { surgical } \\
\text { curability } \\
\text { SCCHN }\end{array}$ & $\begin{array}{l}\text { TPF } \rightarrow \\
\text { carboplatin- } \\
\text { RTX }\end{array}$ & $\begin{array}{c}\mathrm{PF} \rightarrow \\
\text { carboplatin- } \\
\text { RTX }\end{array}$ & OS & $\begin{array}{c}\text { PFS } \\
\text { ORR after } \\
\text { induction-CT } \\
\text { Toxicity }\end{array}$ & $\begin{array}{c}\text { OS } \rightarrow 71 \text { vs } 30 \mathrm{mo} \\
\quad(p=0.006) \\
\begin{array}{c}\text { PFS } \rightarrow 36 \text { vs } 13 \text { mo } \\
(p=0.004)\end{array} \\
\text { ORR } \rightarrow 72 \% \text { vs } 64 \% \\
\quad(p=0.07)\end{array}$ & NA & $\begin{array}{c}<1 \% \text { vs } \\
<1 \%\end{array}$ \\
\hline $\begin{array}{l}\text { Hitt R, Ann } \\
\text { Oncol [7] } \\
\text { (TTCC 2002) }\end{array}$ & $\begin{array}{c}\text { Stage III } \\
\text { or IV non } \\
\text { metastatic, } \\
\text { unresectable } \\
\text { SCCHN }\end{array}$ & $\begin{array}{l}\text { TPF } \rightarrow \\
\text { cisplatin- } \\
\text { RTX } \\
\text { or } \\
\text { PF } \rightarrow \\
\text { cisplatin- } \\
\text { RTX }\end{array}$ & cisplatin-RT & $\begin{array}{l}\text { PFS } \\
\text { TTF }\end{array}$ & $\begin{array}{c}\text { OS } \\
\text { LRC } \\
\text { Toxicity }\end{array}$ & $\begin{array}{c}\text { ITT population: } \\
\text { PFS } \rightarrow 14.6 \text { vs } 14.3 \text { vs } \\
13.8 \text { mo ( } \mathrm{p}=0.56) \\
\text { TTF } \rightarrow 7.9 \text { vs } 7.9 \text { vs } \\
8.2 \text { mo ( } \mathrm{p}=0.90) \\
\text { OS } \rightarrow 27.0 \text { vs } 27.2 \text { vs } \\
26.6 \text { mo (NS) } \\
\text { LRC rate } \rightarrow 52.9 \% \\
\text { vs } 51.3 \% \text { vs } 49.2 \% \\
(p=0.83)\end{array}$ & NA & $\begin{array}{c}2.6 \% \text { vs } \\
4.6 \% \text { vs } \\
1.7 \%\end{array}$ \\
\hline
\end{tabular}




\begin{tabular}{|c|c|c|c|c|c|c|c|c|}
\hline $\begin{array}{l}\text { Pointreau Y, } \\
\text { JNCI [23] } \\
\text { (GORTEC } \\
\text { 2000-01) }\end{array}$ & $\begin{array}{c}\text { Stage III or IV } \\
\text { LA larynx or } \\
\text { hypopharynx } \\
\text { SCCHN }\end{array}$ & $\begin{array}{l}\text { TPF } \rightarrow \text { RTX } \pm \\
\text { CT (cisplatin, } \\
\text { carboplatin, } \\
\text { 5FU or a } \\
\text { combination } \\
\text { of } 2 \text { drugs)/ } \\
\text { surgery }\end{array}$ & $\begin{array}{c}\mathrm{PF} \rightarrow \mathrm{RTX} \pm \\
\text { CT (cisplatin, } \\
\text { carboplatin, } \\
5 \mathrm{FU} \text { or a } \\
\text { combination } \\
\text { of } 2 \text { drugs)/ } \\
\text { surgery }\end{array}$ & $3 y-L P R$ & $\begin{array}{c}\text { OS } \\
\text { ORR to ICT } \\
\text { DFS } \\
\text { Toxicity }\end{array}$ & $\begin{array}{c}3 \mathrm{y}-\mathrm{LPR} \rightarrow 70.3 \% \text { vs } \\
57.5 \%(\mathrm{p}=0.03) \\
3 \mathrm{y}-\mathrm{OS} \rightarrow 60 \% \text { vs } 60 \% \\
(\mathrm{p}=0.57) \\
\text { ORR to ICT } \rightarrow 80.0 \% \\
\text { vs } 59.2 \%(\mathrm{p}=0.002) \\
3 \mathrm{y}-\mathrm{DFS} \rightarrow 58 \% \text { vs } \\
44 \%(\mathrm{p}=0.11)\end{array}$ & $\begin{array}{c}1.9 \% \text { vs } \\
2.7 \%\end{array}$ & NA \\
\hline $\begin{array}{c}\text { Cohen EE, JCO } \\
{[16]} \\
\text { (DeCIDE) }\end{array}$ & $\begin{array}{l}\text { Non } \\
\text { metastatic } \\
\text { N2 or N3 } \\
\text { LASCCHN }\end{array}$ & $\begin{array}{l}\text { TPF } \rightarrow \text { DFHX- } \\
\text { RTX }\end{array}$ & DFHX-RTX & OS & $\begin{array}{c}\text { DF-FS } \\
\text { RFS } \\
\text { Toxicity }\end{array}$ & $\begin{array}{c}\text { OS } \rightarrow \text { NS } \\
\text { ORR } 79 \text { vs } 74 \\
(p=0.45) \\
\text { DF-FS } \rightarrow \text { NS } \\
\text { RFS } \rightarrow \text { NS }\end{array}$ & $2.9 \%$ & $\begin{array}{l}1.4 \% \text { vs } \\
2.2 \% \\
\text { (during } \\
\text { CRT) }\end{array}$ \\
\hline $\begin{array}{c}\text { Haddad R, } \\
\text { Lancet Oncol } \\
\text { [15] } \\
\text { (PARADIGM) }\end{array}$ & $\begin{array}{l}\text { Stage III } \\
\text { or IV non } \\
\text { metastatic } \\
\text { SCCHN }\end{array}$ & $\begin{array}{l}\text { TPF } \rightarrow \text { CRT } \\
\text { (docetaxel or } \\
\text { carboplatin) }\end{array}$ & Cisplatin-RTX & OS & $\begin{array}{c}\text { PFS } \\
\text { Toxicity }\end{array}$ & $\begin{array}{c}3 y-O S \rightarrow 73 \% \text { vs } 78 \% \\
(p=0.77) \\
3 y-P F S \rightarrow 67 \% \text { vs } \\
69 \%(p=0.77)\end{array}$ & NA & NA \\
\hline $\begin{array}{c}\text { Ghi MG, } \\
\text { Ann Oncol } \\
\text { [11] } \\
\text { (Italian trial) }\end{array}$ & $\begin{array}{c}\text { Stage III or IV } \\
\text { LASCCHN }\end{array}$ & $\begin{array}{l}\text { TPF } \rightarrow \text { CRT / } \\
\text { cetuximab- } \\
\text { RTX }\end{array}$ & $\begin{array}{c}\text { CRT/ } \\
\text { cetuximab- } \\
\text { RTX }\end{array}$ & OS & $\begin{array}{c}\text { RR } \\
\text { LRC } \\
\text { PFS } \\
\text { Toxicity }\end{array}$ & $\begin{array}{c}\text { OS } \rightarrow 54.7 \text { vs } 31.7 \mathrm{mo} \\
\quad(\mathrm{p}=0.030) \\
\text { Loco-regional failure } \\
\rightarrow 41 \% \text { vs } 48 \% \\
\quad(\mathrm{p}=0.036) \\
\text { PFS } \rightarrow 30.5 \text { vs } 18.5 \\
\text { mo (p=0.013) }\end{array}$ & $2.4 \%$ & NA \\
\hline
\end{tabular}

Table 2: Toxicity of ICT in clinical trials.

\begin{tabular}{|c|c|c|c|c|c|c|}
\hline \multicolumn{2}{|l|}{ Trial } & Neutropenia & $\begin{array}{c}\text { Febrile } \\
\text { Neutropenia }\end{array}$ & Mucositis & Nausea/Vomiting & Other Toxicities \\
\hline \multirow{2}{*}{ Hitt R, JCO [7] } & ICT & $37 \%$ vs $36 \%$ & $8 \%$ vs $5 \%$ & $\begin{array}{c}\text { G2-4: } 16 \% \text { vs } 53 \% \\
(\mathrm{p}<0.001)\end{array}$ & $6 \%$ vs $8 \%$ & $\begin{array}{l}\text { Alopecia: } 10 \% \text { vs } 2 \% \\
\quad(\mathrm{p}<0.001)\end{array}$ \\
\hline & CRT & $32 \%$ vs $20 \%$ & 0 vs $4 \%$ & $\begin{array}{c}34 \% \text { vs } 55 \% \\
(p=0.004)\end{array}$ & $4 \%$ vs $17 \%(p=0.003)$ & NA \\
\hline $\begin{array}{l}\text { Vermorken J, } \\
\text { NEJM [8] }\end{array}$ & ICT & $76.9 \%$ vs $52.5 \%$ & $5.2 \%$ vs $2.8 \%$ & $4.6 \%$ vs $11.2 \%$ & $\begin{array}{c}\text { Nausea: } 0.6 \% \text { vs } 6.7 \% \\
\text { Vomiting: } 0.6 \% \text { vs } 4.5 \%\end{array}$ & $\begin{array}{c}\text { Alopecia: } 11.6 \% \text { vs } 0 \% \\
\text { Thrombocytopenia: } 5.2 \% \text { vs } \\
17.9 \%\end{array}$ \\
\hline $\begin{array}{c}\text { Posner MR, NEJM } \\
{[9]}\end{array}$ & & $\begin{array}{c}83 \% \text { vs } 56 \% \\
(\mathrm{p}<0.001)\end{array}$ & $\begin{array}{l}12 \% \text { vs } 7 \% \\
(\mathrm{p}<0.04)\end{array}$ & $21 \%$ vs $27 \%(\mathrm{p}=0.14)$ & NS & $\begin{array}{c}\text { Thrombocytopenia: } 4 \% \text { vs } \\
11 \%(\mathrm{p}=0.005)\end{array}$ \\
\hline \multirow{2}{*}{$\begin{array}{l}\text { Hitt R, Ann Oncol } \\
\text { [7] }\end{array}$} & ICT & $19.0 \%$ vs $34.6 \%$ & $17.0 \%$ vs $1.9 \%$ & $9.1 \%$ vs $14.7 \%$ & $\begin{array}{c}\text { Nausea: } 3.3 \% \text { vs } 1.3 \% \\
\text { Vomiting: } 6.6 \% \text { vs } 1.9 \%\end{array}$ & NA \\
\hline & CRT & $\begin{array}{l}30.2 \% \text { vs } 20.2 \% \\
\quad \text { vs } 20.4 \%\end{array}$ & $\begin{array}{l}4.7 \% \text { vs } 0.9 \% \\
\text { vs } 0.9 \%\end{array}$ & $\begin{array}{c}49.0 \% \text { vs } 50.0 \% \text { vs } \\
33.0 \%\end{array}$ & $\begin{array}{c}\text { Nausea: } 2.8 \% \text { vs } 3.5 \% \\
\text { vs } 5.1 \% \text { Vomiting: } 4.7 \% \\
\text { vs } 3.5 \% \text { vs } 8.5 \%\end{array}$ & $\begin{array}{c}\text { Odinofagia: } 13.2 \% \text { vs } 14.9 \% \\
\text { vs } 6.8 \%\end{array}$ \\
\hline $\begin{array}{c}\text { Pointreau Y, JNCI } \\
{[23]}\end{array}$ & & $\begin{array}{c}\text { G4: } 31.5 \% \text { vs } \\
\quad 17.6 \%\end{array}$ & $10.9 \%$ vs $5.8 \%$ & $4.6 \%$ vs $7.8 \%$ & $3.7 \%$ vs $3.9 \%$ & $\begin{array}{c}\text { Thrombocytopenia: } 1.8 \% \text { vs } \\
7.8 \% \text { G4 creatinine elevation: } \\
0 \text { vs } 2.0 \%\end{array}$ \\
\hline \multirow{2}{*}{$\begin{array}{c}\text { Cohen EE, JCO } \\
{[14]}\end{array}$} & ICT & $11 \%$ & NA & $\begin{array}{l}\text { Clinical: } 8.8 \% \\
\text { Functional: } 6.6 \%\end{array}$ & $\begin{array}{c}\text { Nausea: } 3.7 \% \text { Vomiting: } \\
2.2 \%\end{array}$ & \\
\hline & CRT & $\begin{array}{l}3.2 \% \text { vs } 1.5 \% \\
\quad(P=0.13)\end{array}$ & NA & $\begin{array}{l}\text { Clinical: } 51 \% \text { vs } 47 \% \\
\text { (P=0.48) Functional: } \\
47 \% \text { vs } 42 \%(\mathrm{P}=0.32)\end{array}$ & $\begin{array}{c}\text { Nausea: } 5.6 \% \text { vs } 4.5 \% \\
\text { (p=0.16) Vomiting: } \\
3.2 \% \text { vs } 2.3 \%(p=0.89)\end{array}$ & $\begin{array}{l}\text { Higher rates of alopecia, } \\
\text { anemia, hypomagnesemia and } \\
\text { leukopenia in ICT arm }\end{array}$ \\
\hline $\begin{array}{l}\text { Haddad R, Lancet } \\
\text { Oncol [15] }\end{array}$ & & NA & $23 \%$ vs $1 \%$ & $47 \%$ vs $16 \%$ & NA & $\begin{array}{c}\text { No differences in mucositis } \\
\text { and pain scores, xerostomia, } \\
\text { neuropathy, or feeding tube } \\
\text { dependency }\end{array}$ \\
\hline
\end{tabular}




\section{Global Journal of Otolaryngology}

\begin{tabular}{|c|c|c|c|c|c|c|}
\hline \multirow{2}{*}{$\begin{array}{c}\text { Ghi MG, Ann } \\
\text { Oncol [11] }\end{array}$} & ICT & $27.50 \%$ & $11 \%$ & $10 \%$ & $3.40 \%$ & \\
\cline { 2 - 7 } & CRT & 4 vs $1(\mathrm{p}=0.038)$ & 0 vs $1(\mathrm{p}=0.20)$ & 34.5 vs $41(\mathrm{p}=0.166)$ & 0 vs 0 & Dermatitis 1.5 vs 6 (p=0.028) \\
\hline
\end{tabular}

IC has recently become a valid therapeutic option for a large group of LASCCHN patients. The TPF regimen is the best choice since it proved to be more effective and less toxic than the classic PF regimen. Although a large amount of data is available, many unresolved issues still remain on the carpet. Which patients select for maximum benefit, which is the best local treatment after IC, which cumulative dose of cisplatin can be safely administered with IC and concomitant cisplatin-based CRT, how to manage the expected increased toxicity of induction and what will be the role of immunotherapy in the next future are some of the aspects that needs additional clarifications in future clinical trials (Tables 1 \& 2).

\section{References}

1. Study G, Wolf GT, Fisher SG, Hong WK, Hillman R, et al. (1991) Induction chemotherapy plus radiation compared with surgery plus radiation in patients with advanced laryngeal cancer, Department of Veterans Affairs Laryngeal Cancer Study. N Engl J Med 324:1685-16990.

2. Thyss A, Schneider M, Santini J, Caldani C, Vallicioni J (1986) Induction chemotherapy with cis-platinum and 5-fluorouracil for squamous cell carcinoma of the head and neck. Br J Cancer 54: 755-760.

3. Ervin TJ, Clark JR, Weichselbaum RR, Fallon BG, Miller D (1987) An analysis of induction and adjuvant chemotherapy in the multidisciplinary treatment of squamous cell carcinoma of the head and neck. J Clin Oncol 5: 10-20.

4. Schuller DE, Metch B, Stein DW, Mattox D, McCracken JD (1988) Preoperative chemotherapy in advanced resectable head and neck cancer: final report of the Southwest Oncology Group. Laryngoscope 98: $1205-1211$.

5. Pignon JP, Bourhis J (1995) Meta analysis of chemotherapy in head and neck cancer: individual patient data vs literature data. Br J Cancer 72: 1062-1063.

6. Pignon JP, le Maitre A, Maillard E, Bourhis J, Group MNC (2009) Meta analysis of chemotherapy in head and neck cancer (MACH-NC): an update on 93 randomised trials and 17,346 patients. Radiother Oncol 92: $4-14$.

7. Hitt R, Lopez Pousa A, Martinez Trufero J, Escrig V, Carles J (2005) Phase III study comparing cisplatin plus fluorouracil to paclitaxel, cisplatin, and fluorouracil induction chemotherapy followed by chemoradiotherapy in locally advanced head and neck cancer. J Clin Oncol 23: 8636-8645.

8. Vermorken JB, Remenar E, van Herpen C, Gorlia T, Mesia R (2007) Cisplatin, fluorouracil, and docetaxel in unresectable head and neck cancer. N Engl J Med 357: 1695-1704.

9. Posner MR, Hershock DM, Blajman CR, Mickiewicz E, Winquist E (2007) Cisplatin and fluorouracil alone or with docetaxel in head and neck cancer. N Engl J Med 357: 1705-1715.

10. Blanchard P, Bourhis J, Lacas B, Posner MR, Vermorken JB (2013) Taxane cisplatin fluorouracil as induction chemotherapy in locally advanced head and neck cancers: an individual patient data metaanalysis of the meta-analysis of chemotherapy in head and neck cancer group. J Clin Oncol 31: 2854-2860.

11. Ghi MG, Paccagnella A, Ferrari D, Foa P, Alterio D (2017) Induction TPF followed by concomitant treatment versus concomitant treatment alone in locally advanced head and neck cancer. A phase II-III trial Ann Oncol 28: 2206-2212.
12. van Herpen CM, Mauer ME, Mesia R, Degardin M, Jelic S (2010) Short term health related quality of life and symptom control with docetaxel, cisplatin, 5 fluorouracil and cisplatin (TPF), 5-fluorouracil (PF) for induction in unresectable locoregionally advanced head and neck cancer patients (EORTC 24971/TAX 323). Br J Cancer 103 (8): 11731181.

13. Improving outcomes in head and neck cancers.

14. Lo Nigro C, Denaro N, Merlotti A, Merlano M (2017) Head and neck cancer: improving outcomes with a multidisciplinary approach. Cancer Manag Res 9: 363-371.

15. Haddad R, O'Neill A, Rabinowits G, Tishler R, Khuri F (2013) Induction chemotherapy followed by concurrent chemoradiotherapy (sequential chemoradiotherapy) versus concurrent chemoradiotherapy alone in locally advanced head and neck cancer (PARADIGM): a randomised phase 3 trial. Lancet Oncol 14: 257-264.

16. Cohen EE, Karrison TG, Kocherginsky M, Mueller J, Egan R (2014) Phase III randomized trial of induction chemotherapy in patients with N2 or N3 locally advanced head and neck cancer. J Clin Oncol 32 (25): 2735-2743.

17. Misiukiewicz K, Gupta V, Posner M (2017) The Italian Collaborative Group sets a standard for the treatment of locally advanced head and neck cancer. Ann Oncol 28: 2051-2054.

18. Henriques De Figueiredo B, Fortpied C, Menis J, Lefebvre JL, Barzan L (2016) Long-term update of the 24954 EORTC phase III trial on larynx preservation. Eur J Cancer 65: 109-112.

19. Villar A, Pera J, Arellano A, Galiana R, Villa S (1987) Induction chemotherapy with cisplatin, bleomycin and methotrexate in advanced head and neck cancer lack of therapeutic gain. Radiother Oncol 10 (3): 175-181.

20. Ma J, Liu Y, Yang X, Zhang CP, Zhang ZY et al. (2013) Induction chemotherapy in patients with resectable head and neck squamous cell carcinoma: a meta analysis. World J Surg Oncol 11: 67.

21. Spaulding MB, Fischer SG, Wolf GT (1994) Tumor response, toxicity, and survival after neoadjuvant organ-preserving chemotherapy for advanced laryngeal carcinoma. The Department of Veterans Affairs Cooperative Laryngeal Cancer Study Group. J Clin Oncol 12 (8): 15921599.

22. Lefebvre JL, Rolland F, Tesselaar M, Bardet E, Leemans CR, et al. (2009) Phase 3 randomized trial on larynx preservation comparing sequential vs alternating chemotherapy and radiotherapy. J Natl Cancer Inst 101(7): 142-152.

23. Pointreau Y, Garaud P, Chapet S, Sire C, Tuchais C (2009) Randomized trial of induction chemotherapy with cisplatin and 5-fluorouracil with or without docetaxel for larynx preservation. J Natl Cancer Inst 101(7): 498-506.

24. Forastiere AA, Zhang Q, Weber RS, Maor MH, Goepfert H (2013) Long term results of RTOG 91-11: a comparison of three nonsurgical treatment strategies to preserve the larynx in patients with locally advanced larynx cancer. J Clin Oncol 31(7): 845-852.

25. Lefebvre JL, Pointreau Y, Rolland F, Alfonsi M, Baudoux A (2013) Induction chemotherapy followed by either chemoradiotherapy or bioradiotherapy for larynx preservation: the TREMPLIN randomized phase II study. J Clin Oncol 31: 853-859.

26. Gillison ML, D Souza G, Westra W, Sugar E, Xiao W, et al. (2008) Distinct risk factor profiles for human papillomavirus type 16-positive and human papillomavirus type 16-negative head and neck cancers. J Natl Cancer Inst 100(6): 407-420. 
27. Rampias T, Sasaki C, Weinberger P, Psyrri A (2009) E6 and e7 gene silencing and transformed phenotype of human papillomavirus 16-positive oropharyngeal cancer cells. J Natl Cancer Inst 101: 412 423

28. Ragin CC, Taioli E (2007) Survival of squamous cell carcinoma of the head and neck in relation to human papillomavirus infection: review and meta-analysis. Int J Cancer 121(8): 1813-1820.

29. Fakhry C, Westra WH, Li S, Cmelak A, Ridge JA (2008) Improved survival of patients with human papillomavirus-positive head and neck squamous cell carcinoma in a prospective clinical trial. J Nat Cancer Inst 100(4): 261-269.

30. Ang KK, Harris J, Wheeler R, Weber R, Rosenthal DI (2010) Human papillomavirus and survival of patients with oropharyngeal cancer. $\mathrm{N}$ Engl J Med 363(1): 24-35.

31. Posner MR, Lorch JH, Goloubeva O, Tan M, Schumaker LM (2011) Survival and human papillomavirus in oropharynx cancer in TAX 324: a subset analysis from an international phase III trial. Ann Oncol 22(5): 1071-1077.

32. Rainey H, Roy E, Selkridge I (2017) Standard of care vs reduced-dose chemoradiation after induction chemotherapy in HPV+ oropharyngeal carcinoma patients. J Clin Oncol 35(15): 6069.

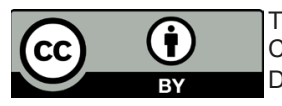

This work is licensed under Creative Commons Attribution 4.0 License

DOI: 10.19080/GJO.2018.16.555934
33. Marur S, Li S, Cmelak AJ, Gillison ML, Zhao WJ (2017) E1308: Phase II Trial of Induction Chemotherapy Followed by Reduced Dose Radiation and Weekly Cetuximab in Patients With HPV-Associated Resectable Squamous Cell Carcinoma of the Oropharynx- ECOG-ACRIN Cancer Research Group. J Clin Oncol 35 (5): 490-497.

34. Bossi P, Lo Vullo S, Guzzo M, Mariani L, Granata R (2014) Preoperative chemotherapy in advanced resectable OCSCC: long-term results of a randomized phase III trial. Ann Oncol 25(2): 462-466.

35. Kim DH, Kim WT, Lee JH, Ki YK, Nam JH (2015) Analysis of the prognostic factors for distant metastasis after induction chemotherapy followed by concurrent chemoradiotherapy for head and neck cancer. Cancer Res Treat 47: 46-54.

36. Zhong LP, Zhang CP, Ren GX, Guo W, William WN (2013) Randomized phase III trial of induction chemotherapy with docetaxel, cisplatin, and fluorouracil followed by surgery versus up-front surgery in locally advanced resectable oral squamous cell carcinoma. J Clin Oncol 31(6): 744-751.

\section{Your next submission with Juniper Publishers} will reach you the below assets

- Quality Editorial service

- Swift Peer Review

- Reprints availability

- E-prints Service

- Manuscript Podcast for convenient understanding

- Global attainment for your research

- Manuscript accessibility in different formats ( Pdf, E-pub, Full Text, Audio)

- Unceasing customer service

Track the below URL for one-step submission https://juniperpublishers.com/online-submission.php 